\title{
Pengaruh Pakan Komersial Terfermentasi EM4 terhadap Pertambahan Bobot Badan, Konsumsi Pakan, dan Konversi Pakan Ayam Broiler
}

\section{Imelda Boki}

Fakultas Pertanian, Universitas Timor, Kefamenanu, TTU - NTT, Indonesia, email: Imleda.boki@yahoo.com

\section{Article Info}

Article history:

Received 18 Juni 2019

Received in revised form 20 Januari 2020 Accepted 14 Maret 2020

DOI:

https://doi.org/10.32938/ja.v5i2.759

Keywords:

Broiler

Fermentasi

$\mathrm{PBB}$

Konversi pakan

EM4

\section{Abstrak}

Penelitian ini bertujuan untuk mengetahui pengaruh pakan komersial terfermentasi EM4 terhadap pertambahan bobot badan, konsumsi pakan dan konversi pakan ayam broiler. Penelitian ini dilaksanakan di Kefamenanu, Timor Tengah Utara dari bulan April sampai Mei 2019. Materi yang digunakan dalam penelitian ini adalah Day Old Chick (DOC) broiler PT. Wonokoyo sejumlah 80 ekor. Pakan yang digunakan adalah pakan komersial yang difermentasi dengan EM4. Penelitian ini menggunakan Rancangan Acak Lengkap (RAL) yang terdiri dari 4 perlakuan dan 4 ulangan. Perlakuan yang diberikan adalah R0: pakan komersial (kontrol), R1: pakan komersial terfermentasi $5 \mathrm{ml} \mathrm{EM} 4 / \mathrm{kg}, \mathrm{R} 2$ : pakan komersial terfermentasi $10 \mathrm{ml} \mathrm{EM} 4 / \mathrm{kg}$. R3: pakan komersial terfermentasi $15 \mathrm{ml}$ EM4/kg. Variabel yang diteliti adalah pertambahan bobot badan, konsumsi pakan dan konversi pakan. Hasil penelitian menunjukan bahwa pakan komersial yang difermentasi dengan EM4 mempengaruhi pertambahan bobot badan, konsumsi pakan dan konversi pakan ayam broiler $(\mathrm{P}<0,01)$. Disimpulkan bahwa pakan komersial dapat difermentasi dengan EM4 $15 \mathrm{ml} / \mathrm{kg}$ memberikan hasil terbaik pada pertambahan berat badan dan konversi pakan ayam broiler.

\section{Pendahuluan}

Pemenuhan kebutuhan protein hewani tidak terlepas dari peningkatan populasi ternak yang berimbas pada peningkatan jumlah dan kualitas produk Peningkatan produksi ternak tergantung pula dari pola dan kualitas pakan. Produksi ternak akan maksimal jika peningkatan efesiensi kecernaan bahan pakan dan nutrisi terjadi secara optimal (Winedar et al., 2006). Ayam pedaging (broiler) merupakan salah satu sumber protein yang murah, berupa daging yang merupakan kebutuhan masyarakat yang semakin meningkat. Keunggulan dari ayam broiler adalah dapat dijual sebelum 8 minggu. Pada usia itu bera tubuhnya hampir sama dengan tubuh ayam kampung yang berusia satu tahun, sehingga ayam pedaging merupakan saingan baru ayam kampung yang dikembangbiakkan untuk pemasaran pada umur dini. Pertumbuhan ayam pedaging (broiler) dapat disebabkan oleh faktor internal dan faktor eksternal. Salah satu faktor utama dari lingkungan adalah pakan yang berkualitas dan seimbang nutriennya. Hal ini juga didukung dengan pencernaan maupun absorbsi apabila saluran pencernaan memungkinkan. Di dalam saluran pencernaan terdapat banyak bakteri negatif yang menghalangi pencernaan maupun penyerapan nutrien. Untuk meminimalkan kerja bakteri negatif, biasanya digunakan antibiotik. Penggunaan antibiotik mempunyai efek negatif yaitu bakteri positif yang sangat berguna bagi ayam broiler dan usus iku musnah. Selain itu residu antibiotik masih tertinggal dalam hati dan daging ayam.

Hal ini membahayakan konsumen dalam mengkonsumsi daging ayam broiler tersebut. Salah satu cara untuk menghalangi populasi dan kerja bakteri negatif adalah pemberian probiotik. Kim et al.(1988) menyatakan bahwa penambahan probiotik dalam ransum dapat meningkatkan pertambahan bobot badan, menurunkan konversi pakan dan mortalitas. Penggunaan probiotik sebagai bahan pakan tambahan juga dapat meningkatkan pertambahan bobot badan, konversi pakan dan kesehatan ternak serta merupakan alternatif yang aman karena aktifitasnya dalam mendukung perkembangan mikroba yang menguntungkan dan menekan pertumbuhan bakteri patogen dalam saluran pencernaan. Pemberian probiotik memiliki tujuan yaitu untuk meningkatkan pertumbuhan, meningkatkan kecernaan pakan dan meningkatkan pertumbuhan mikroba yang menguntungkan (Fuler, 1997). Probiotik adalah salah satu makanan tambahan berupa mikroba hidup yang menguntungkan pada hewan dengan meningkatkan mikroba dalam saluran pencernaan. Mikroba hidup mampu menghalangi bakteri yang bersifat negatif sehingga dapa menguntungkan pertumbuhan yang bersifat positif. Salah satu cara dengan pemberian probiotik Effective Microorganime (EM4). EM4 bermanfaa menyehatkan ternak, mengurangi stres pada ternak, mengeimbangkan mikroorganisme dalam saluran pencernaan ternak, meningkatkan nafsu makan dan menguranggi polusi atau bau kandang dan lingkungan. Proses fermentas dapat menyederhanakan partikel bahan pakan, sehingga akan meningkatkan nilai gizinya. Bahan pakan yang telah mengalami fermentasi akan lebih baik kualitasnya dari bahan asli. Fermentasi diharapkan daapt meningkatkan efesiensi penggunaan bahan, sehingga pertumbuhan dan bobot karkas ayam broiler akan meningkat (Surung, 2008). Tujuan dari penelitian ini adalah untuk mengetahui pengaruh pemberian pakan komersial yang difermentasikan dengan EM4.

\section{Metode}

Penelitian ini telah dilaksanakan di Kelurahan kefa selatan, Kecamatan Kota Kefamenanu, Kabupaten Timor Tengah Utara. Penelitian berlangsung selama 1 periode pemeliharaan (45 hari) yaitu dari bulan April 2019 sampai Mei 2019. Penelitian ini menggunakan Rancangan Acak Lengkap yang terdiri dari 4 perlakuan dan 4 ulangan, sehingga terdapat 16 unit satuan percobaan. Tiap satuan percobaan terdiri dari 5 ekor ayam broiler sehingga total ternak broiler yang digunakan dalam penelitian ini sebanyak 80 ekor. Adapun perlakuan yang diuji terdiri dari:

R0: Pakan komersial (kontrol)

R1: Pemberian pakan dengan campuran $5 \mathrm{ml}$ EM4/kg pakan komersial yang difermentasi selama 14 hari

R2: Pemberian pakan dengan campuran $10 \mathrm{ml} \mathrm{EM4/kg} \mathrm{pakan} \mathrm{komersial} \mathrm{yang}$ difermentasi selama 14 hari

R3: Pemberian pakan dengan campuran $15 \mathrm{ml}$ EM4/kg pakan komersial yang difermentasi selama 14 hari.

2.1 Prosedur Penelitian

Beberapa tahap yang dilakukan dalam penelitian adalah:

1. Persiapan kandang.

2. Seluruh ruang kandang dicucihamakan dengan antiseptik (neo antisep) seminggu sebelum penelitian.

3. Peralatan makan dan minum dibersihkan dan dicucihamakan dengan neo antisep.

4. Persiapan bahan kandang seperti alas kandang (sekam dan kapur)

5. Setelah DOC tiba tindakan selanjutnya adalah:

a. DOC diistirahatkan $\pm 1 / 2$ jam

b. Pemberian air gula

c. Pemberian pakan awal yang diberikan di tempat makan yang telah disiapkan. Pemberian air minum dicampur dengan vitamin.

6. Pada umur 3 hari dilakukan vaksinasi ND1 melalui tetes mata.

7. Pemberian pakan dan air minum yang dicampur dengan vitamin hingga ayam berumur 10 hari

8. Pada umur 10 hari penempatan ayam di dalam kandang dilakukan secara acak sesuai perlakuan.

9. Adaptasi pakan sesuai perlakuan pada hari ke 11 sampai 14 .

10. Pemberian perlakuan pada hari pertama sampai panen

11. Pada umur 21 hari diberikan vaksin ND2.

12. Pengambilan data selama penelitian berlangsung.

Pada awal pemberian perlakuan, terlebih dahulu ternak diadaptasikan terhadap pakan, lingkungan dan kandang selama 4 hari, setelah itu ternak diberi pakan sesuai perlakuan. Pengambilan data konsumsi pakan setiap hari, minggu kedua (hari ke 14) ayam diberi perlakuan sedangkan berat badan ditimbang tiap minggu.

\subsection{Variabel Penelitian}

Variabel yang diamati dalam penelitian ini adalah:

1. Pertambahan berat badan (PBB) yaitu selisih antara berat badan akhir dengan berat badan awal dibagi total hari penelitian (g/ekor/hari)

Pertambahan berat badan $(\mathrm{g} / \mathrm{ekor} /$ hari $)=\frac{\text { berat badan akhir-berat badan awal }}{\text { a }}$

2. Konsumsi pakan yaitu selisih antara jumlah pakan yang diberikan dan sisa pakan yang tidak dikonsumsi (g/ekor/hari).

Konsumsi pakan $(\mathrm{g} / \mathrm{ekor} / \mathrm{hari})=\frac{\text { pakan beri-pakan sissa }}{\text { Lama Pemeliharaan }}$

3. Konversi Pakan yaitu jumlah pakan yang dikonsumsi dibagi pertambahan berat badan. Konversi pakan dihitung dengan rumus

Konversi pakan $=\frac{\text { konsumsi pakan }}{\text { pertambahan berat badan }}$

\subsection{Prosedur Pengambilan Data}




\subsection{Analisis Data}

Data yang diperoleh dalam penelitian ini dianalisis dengan menggunakan analisis sidik ragam (Anova) sesuai dengan Rancangan Acak Lengkap (RAL), dilanjutkan dengan uji jarak berganda Duncan untuk melihat perbedaan antara perlakuan (Stell and Torrie, 1995).

Rumus matematikanya adalah: $Y \mathrm{ij}=\mu+\tau \mathrm{i}+\varepsilon \mathrm{ij}$

Keterangan :

Yij : pengamatan perlakuan ke-i dan ulangan ke-j

$\mu \quad$ : rata-rata umum

$\tau$ i : pengaruh perlakuan ke-i

cij : galat perlakuan ke-i dan ulangan ke-j.

\section{Hasil dan Pembahasan}

3.1 Pengaruh Perlakuan Terhadap Pertambahan Berat Badan Ayam Broiler

Pertambahan bobot badan mencerminkan tingkat kemampuan ternak dalam mencerna ransum untuk diubah menjadi bobot badan. Pertambahan bobot badan sangat berkaitan dengan pakan, dalam hal kuantitas yang berkaitan dengan konsumsi pakan apabila konsumsi pakan terganggu maka akan mengganggu pertumbuhan (Uzer et al., 2013). Rata-rata pertambahan berat badan ayam broiler terlihat pada Tabel 1 .

Tabel 1. Rata-rata pertambahan berat badan ayam broiler (g/ekor/hari)

\begin{tabular}{|c|c|c|c|c|c|c|}
\hline \multirow{2}{*}{ Perlakuan } & \multicolumn{4}{|c|}{ Ulangan } & \multirow[b]{2}{*}{ Jumlah } & \multirow[b]{2}{*}{ Rata-rata } \\
\hline & 1 & 2 & 3 & 4 & & \\
\hline R0 & 42,80 & 39,00 & 38,40 & 45,26 & 165,46 & $41,37^{\mathrm{c}}$ \\
\hline $\mathrm{R} 1$ & 47,70 & 37,21 & 48,98 & 45,96 & 179,85 & $44,96^{\mathrm{bc}}$ \\
\hline $\mathrm{R} 2$ & 47,21 & 47,21 & 48,76 & 46,09 & 189,27 & $47,32^{\mathrm{ab}}$ \\
\hline R3 & 53,03 & 47,25 & 55,76 & 53,84 & 209,88 & $52,47^{\mathrm{a}}$ \\
\hline
\end{tabular}

Pertambahan bobot badan tertinggi dalam penelitian ini adalah perlakuan R3 dengan tambahan $15 \mathrm{ml}$ EM4/kg pakan komersial yang difermentasikan selama 14 hari sebesar 52,47 g/ekor, kemudian diikuti oleh perlakuan R2 dengan pertambahan bobot badan sebesar 47,32 g/ekor, R1 44,96 g/ekor dan yang terendah perlakuan R0 dengan pertambahan berat badan sebesar 41,37 g/ekor. Analisis sidik ragam memperlihatkan bahwa penambahan probiotik EM4 dalam ransum yang difermentasi selama 14 hari memberikan pengaruh yang sangat nyata $(\mathrm{P}<0,01)$ terhadap pertambahan berat badan harian. Hasil uji jarak berganda Duncan menunjukkan bahwa pada pasangan perlakuan $R_{3}-R_{1}$, $\mathrm{R}_{3}-\mathrm{R}_{0}$ dan $\mathrm{R} 2-\mathrm{R} 0$ memiliki perbedaan yang sangat nyata terhadap nilai pertambahan berat badan harian ayam broiler. Hal ini terjadi akibat adanya penambahan probitik EM4 dalam ransum yang telah difermentasi selama 14 hari. Fermentasi pakan komersial dengan EM4 meningkatkan kecernaan pakan sehingga berpengaruh pada pertambahan berat badan harian ayam broiler. Hal ini sejalan dengan pendapat Suwarno et al., (2015) bahwa pemberian probiotik berpengaruh terhadap pertumbuhan ayam broiler. Kemudian dilanjutkan oleh Winarno dan Fardiaz (1980) bahwa bahan pakan yang mengalami fermentasi dapat meningkatkan nilai gizinya jika dibandingkan dengan bahan aslinya Qurniawan (2016) berpendapat bahwa faktor yang berpengaruh pada pertambahan bobot badan yaitu perbedaan jenis kelamin, konsumsi pakan, lingkungan, bibit dan kualitas pakan.

\subsection{Pengaruh Perlakuan Terhadap Konsumsi Pakan Ayam Broiler}

Konsumsi pakan merupakan jumlah pakan yang dimakan dalam jangka waktu tertentu. Konsumsi pakan yaitu selisih antara jumlah pakan yang diberikan dan sisa pakan yang tidak dikonsumsi (gram/ekor/hari) (Irawan et al., 2012). Rata-rata konsumsi pakan ayam broiler terlihat pada Tabel 2.

Tabel 2. Rata-rata konsumsi pakan ayam broiler (g/ekor/hari)

\begin{tabular}{|c|c|c|c|c|c|c|}
\hline \multirow[b]{2}{*}{ Perlakuan } & \multicolumn{4}{|c|}{ Ulangan } & \multirow[b]{2}{*}{ Jumlah } & \multirow[b]{2}{*}{ Rata-rata } \\
\hline & 1 & 2 & 3 & 4 & & \\
\hline R0 & 154,09 & 153,69 & 155,65 & 158,46 & 621,89 & $155,47^{\mathrm{a}}$ \\
\hline R1 & 146,71 & 150,67 & 149,98 & 155,80 & 603,16 & $150,79^{b}$ \\
\hline R2 & 148,26 & 147,77 & 152,21 & 152,52 & 600,76 & $150,19^{b}$ \\
\hline R3 & 145,69 & 145,88 & 144,86 & 147,41 & 583,84 & $145,96^{\mathrm{c}}$ \\
\hline
\end{tabular}

Rata-rata konsumsi ransum ayam broiler tertinggi pada perlakuan R0 yaitu sebesar 155,47 g/ekor, diikuti perlakuan R1 sebesar 150,79 g/ekor, R2 150,19 g/ekor dan yang tererendah pada perlakuan R3 dengan rerata konsumsi ransum sebesar 145,96 g/ekor. Analisis sidik ragam mengindikasikan bahwa penggunaan probiotik EM4 dalam ransum yang difermentasi selama 14 hari berpengaruh yang sangat nyata $(\mathrm{P}<0,01)$ terhadap konsumsi ransum. Uji Duncan menunjukkan bahwa pada pasangan perlakuan R0-R1, R0-R2, R0-R3, R1-R3 dan R2-R3 memiliki perbedaan yang sangat nyata $(P<0,01)$ terhadap nilai konsumsi ransum broiler. Sedangkan pada pasangan perlakuan R1-R2 tidak terdapat perbedaan. Hal ini menunjukkan bahwa dengan tambahan probiotik EM4 dalam pakan yang difermentasi telah meningkatkan nilai protein dalam pakan tersebut sehingga dapat memenuhi kebutuhan energi dari protein yang dibutuhkan ternak yang ditunjukkan dengan tingkat konsumsi pakan yang lebih sedikit pada perlakuan R1, R2 dan R3 bila dibandingkan dengan perlakuan R0. Hal ini didukung oleh Winedar et al. (2006) bahwa proses fermentasi dengan menggunakan EM4 dapat meningkatkan kandungan protein pada pakan. Selanjutnya Sio et al. (2015) menyatakan bahwa kebutuhan energ dari bahan karbohidrat dalam tubuh jika belum terpenuhi maka ayam menggunakan energi dari bahan lemak ataupun protein yang menyebabkan konsumsi ransum menjadi lebih tinggi jika didalam ransum kandungan energinya rendah. Perbedaan kandungan nutrien yang terdapat dalam pakan seperti protein dan energi termetabolisme mengakibatkan perbedaan konsumsi pakan. Ayam akan berhenti mengkonsumsi pakan jika kebutuhan energi telah terpenuhi. Sekalipun tembolok ayam broiler kosong namun energi di dalam tubuh telah terpenuhi maka ayam akan berhenti mengkonsumsi ransum (Sio et al., 2015).

\subsection{Pengaruh Perlakuan Terhadap Konversi Pakan Ayam Broiler}

Konversi pakan (Feed Convertion Ratio) adalah perbandingan jumlah konsumsi ransum pada satu minggu dengan pertambahan bobot badan, bila rasio kecil berarti pertambahan bobot badan ayam memuaskan atau ayam makan dengan efisien. Nilai konversi pakan ayam broiler tersaji pada Tabel 3.

Tabel 3. Nilai konversi pakan ayam broiler

\begin{tabular}{|c|c|c|c|c|c|c|}
\hline \multirow[b]{2}{*}{ Perlakuan } & \multicolumn{4}{|c|}{ Ulangan } & \multirow[b]{2}{*}{ Jumlah } & \multirow[b]{2}{*}{ Rata-rata } \\
\hline & 1 & 2 & 3 & 4 & & \\
\hline R0 & 3,60 & 3,94 & 4,05 & 3,50 & 15,09 & $3,77^{\mathrm{a}}$ \\
\hline R1 & 3,08 & 4,05 & 3,06 & 3,39 & 13,58 & $3,40^{\mathrm{ab}}$ \\
\hline R2 & 3,14 & 3,13 & 3,12 & 3,31 & 12,70 & $3,18^{\mathrm{bc}}$ \\
\hline R3 & 2,75 & 3,09 & 2,60 & 2,74 & 11,18 & $2,80^{\mathrm{c}}$ \\
\hline
\end{tabular}

Pada Tabel 3 terlihat bahwa rata-rata konversi pakan ayam broiler yang mengkonsumsi ransum komersial yang difermentasi selama 14 hari tanpa tambahan probiotik EM4 adalah 3,77 lebih tinggi dibanding ayam broiler yang mengkonsumsi ransum dengan tambahan probiotik EM4 yaitu 3,40 pada perlakuan R1, 3,18 pada perlakuan R2 dan 2,80 pada perlakuan R3. Jika dilihat dari tingkat konsumsi pakan dan pertambahan bobot badan yang dicapai pada masing-masing perlakuan dapat diketahui bahwa pada perlakuan R3 yang mendapat pertambahan berat badan tertinggi namun konsumsi dan konversi pakannya rendah. Hal ini menunjukkan bahwa dengan tambahan EM4 pada pakan yang difermentasi telah nilai gizi pakan tersebut sehingga pakan yang dikonsumsi dapat dikonversi dengan baik menjadi daging yang ditunjukan dengan nilai pertambahan berat badan yang tinggi. Menurut Allama et al (2012) bahwa nilai konversi pakan yang rendah menunjukkan bahwa efisiensi penggunaan pakan yang baik, karena semakin efisien ayam mengkonsumsi pakan untuk memproduksi daging.

Analisis sidik ragam menunjukkan bahwa penggunaan probiotik EM4 dalam ransum yang difermentasi selama 14 hari berpengaruh sangat nyata $(\mathrm{P}<0,01)$ terhadap konversi pakan. Hasil uji jarak berganda Duncan menunjukkan bahwa pada pasangan perlakuan R0-R1, R0-R2, R0-R3, R1-R2, R1-R3 dan R2-R3 memiliki perbedaan yang sangat nyata lebih tinggi terhadap nilai konversi pakan ayam broiler. Hal ini karena dengan adanya penambahan probiotik EM4 pada pakan yang difermentasi telah meningkatkan nilai gizi pakan tersebut. Semakin tinggi kandungan nilai gizi dalam pakan yang akan diberikan kepada seekor ternak maka ternak tersebut akan mengkonversikan ransum tersebut dengan baik. Hal ini sejalan dengan Sio et al. (2015) bahwa semakin rendah angka konversi pakan berarti kualitas ransum semakin baik

\section{Simpulan}

Dari hasil dan pembahasan dapat disimpulkan bahwa pemberian pakan komersial yang difermentasikan dengan EM4 $15 \mathrm{ml} / \mathrm{kg}$ memberikan hasil terbaik pada pertambahan berat badan dan konversi pakan ayam broiler.

\section{Pustaka}

Allama, H., O. Sofyan, E. Widodo dan H. S. Prayogi. 2012. Pengaruh penggunaan tepung ulat kandang (Alphitobius diaperinus) dalam pakan terhadap penampilan produksi ayam pedaging. J. Ilmu-Ilmu Peternakan, 22(3): $1-8$.

Fuller, R. 1997. Probiotic 2. Application and Practical Appects. $1^{\text {st }}$. Ed Chapman and Hall, London.

Irawan, I., Sunarti dan L. D. Mahfudz. 2012. Pengaruh Pemberian Pakan Bebas Pilih Terhadap Kecernaan Protein Burung Puyuh (Coturnix coturnix japonica). Animal Agriculture Journal, 1 (2) : 238-245.

Kim, C.J., Namkung, H.An.M.S. and paik, L.K. 1988. Suplementation ofprobiotics to the broiler diets containing moldy corn. Korean Journal of Animal Science 30: 542-548.

Qurniawan, A. 2016. Kualitas daging dan performa ayam broiler di kandang terbuka pada ketinggian tempat pemeliharaan yang berbeda $\mathrm{d}$ Kabupaten Takalar Sulawesi Selatan. Tesis. Program Pascasarjana, Institut Pertanian Bogor.

Sio A.K., O. R. Nahak dan A. A. Dethan. 2015. Perbandingan penggunaan dua jenis ransum terhadap $\mathrm{PBBH}$, konsumsi ransum dan konversi ransum ayam broiler. Journal of Animal Science, 1(1): 1-3. 
Suwarno., Sajidan., D. Oetomo dan S. Dwiastuti. 2015. Pengaruh Probiotik Terhadap Pertumbuhan Ayam Broiler. Seminar Nasional XII Pendidikan Biologi, FKIP UNS, p 450-453. Surakarta.

Surung M. Y., 2008. Pengaruh Dosis EM4 (Effective Microorganism-4) dalam Air Minum Terhadap Berat Badan Ayam Buras. Jurnal Agrisistem, 4 (2) 25-30.

Steel, R. G. D. dan J. H. Torrie., 1995. Prinsip dan Prosedur Statistika (Pendekatan Biometrik) Penerjemah B. Sumantri. Gramedia Pustaka Utama, Jakarta.

Uzer, F., N. Iriyanti dan Roesdiyanto. 2013. Penggunaan pakan fungsional dalam ransum terhadap konsumsi pakan dan pertambahan bobot badan ayam broiler. J. Ilmiah Peternakan, 1(1): 282-288.

Winarno, F.G. dan O. Fardiaz. 1980. Pengantar Teknologi Pangan. PT Gramedia. Jakarta.

Winedar, H., S. Listyawati dan Sutarno. 2006. Daya cerna protein pakan, kandungan protein daging, dan pertambahan berat badan ayam broiler setelah pemberian pakan yang difermentasi dengan Effective microorganisme-4 (EM-4). Jurnal Bioteknologi, 2(1):14-19. 